\title{
Management Dilemmas in Patients with Traumatic Brain Injury on Anticoagulants
}

\author{
Srinivas Dwarakanath ${ }^{1}$ Harsh Deora ${ }^{1}$ \\ ${ }^{1}$ Department of Neurosurgery, National Institute of Mental Health
and Neurosciences, Bengaluru, Karnataka, India
}

\begin{abstract}
Address for correspondence Dwarakanath Srinivas, MS, MCh, Department of Neurosurgery, National Institute of Mental Health and Neurosciences, Bengaluru 560029, Karnataka, India (e-mail: drdwaraka@gmail.com).
\end{abstract}

\begin{abstract}
Keywords

- traumatic brain injury

- contusion

- anticoagulants

- antiplatelets

Introduction A normal individual with normal hemostasis maintains a balance between thrombus formation and destruction using a complex interaction between the smooth vascular endothelium, the coagulation cascade, the platelet aggregation system, and the fibrinolysis mechanism. However, in patients who are on either antiplatelet drugs (APDs) or anticoagulants (ACDs), this normal homeostasis is altered. This is further altered with traumatic brain injury (TBI) and thus, we need specific guidelines to address this subpopulation to decide the length of observation, avoid unnecessary hospitalization, and relieve the economic burden. There exists a very few randomized controlled trials (RCTs) for this clinical question and a thorough riskbenefit analysis for each patient is prudent before making clinical decisions.

Materials and Methods This is a review article based on available evidence published in literature.

Results There are multiple therapeutic drugs which act on various stages of the coagulation mechanism. These include antiplatelet agents, Vitamin K antagonists, Heparin, Antithrombin III, and Glycoprotein IIb/IIIA inhibitors. While the initial management of head injuries depends on the severity of head injuries, management of head injuries in patients on anticoagulants needs to be approached with care and caution. There are multiple dilemmas including role of CT scans, duration and reason for admission, when to restart anticoagulation, etc. We suggest the recommendations based on available literature; however, no evidence can be given as these are not based on any RCTs, due to paucity of such studies.

Conclusion The guidelines are based on previously conducted trials and consensus. We have attempted to provide a pragmatic and practical approach to such cases with the hope that it will ensure minimum risks with the best possible patient outcomes. The entire journey from patient presentation to follow-up has been covered in this article and we hope this would be useful to all practicing in the field of neurotrauma.
\end{abstract}

\section{Introduction}

A normal individual with normal hemostasis maintains a balance between thrombus formation and destruction using a complex interaction between the smooth vascular endothelium, the coagulation cascade, the platelet aggregation
DOI https://doi.org/

$10.1055 / \mathrm{s}-0040-1713348$

ISSN 0973-0508. system, and the fibrinolysis mechanism. However, in patients who are on either antiplatelet drugs (APDs) or anticoagulants (ACDs), this normal homeostasis is altered. This is further altered with traumatic brain injury (TBI) and thus, we need specific guidelines to address this subpopulation to decide the length of observation, avoid unnecessary hospitalization,

CC2020 Neurotrauma Society of India

License terms

()(1) $\Theta \circledast$ 
and relieve the economic burden. To be on the safer side, physicians often err on the side of caution and allow for a prolonged period of observation and obtain repeat head imaging. This can lead to prohibitively higher caseloads and even higher costs with undue radiation exposure for such cases.

There exists a very few randomized controlled trials (RCTs) for this clinical question and hence the evidence is weak at best. Despite this, there remains an acute need for clear and precise guidelines on how to manage such cases. A thorough risk-benefit analysis for each patient is prudent before making clinical decisions. The need is further compounded when we take into account the number of elderly who suffer from TBI-up to $7 \%$ in one study. ${ }^{1}$ There are a significant number of individuals in this age group who are on anticoagulants due to cardiovascular diseases and to make matters worse, mortality rates in TBI are higher in this age group. Thus, the intake of these drugs can increase the risk of intracerebral bleed further in these cases and with the absence of specific guidelines, it only makes matters worse. We suggest the following recommendations based on available literature; however, they cannot be given any level of evidence as these are not based on any RCTs due to paucity of such studies.

\section{Mechanism of Action of Commonly used Antiplatelet Drugs and Anticoagulants}

Historically, vitamin K antagonists (VKAs), such as warfarin, were the only anticoagulants widely available for human use. They act by blocking the vitamin $\mathrm{K}$-epoxide reductase, thereby preventing the formation of the active form of the vitamin K-dependent clotting factors. The VKAs have an initial prothrombotic effect, by initially blocking proteins $\mathrm{C}$ and $\mathrm{S}$, followed by a delayed antithrombotic effect, through the inhibition of coagulation factors II, VII, IX, and X. Antithrombin III is a peptide that inhibits several of the activated clotting factors. Unfractionated heparin (UFH) binds to and increases the activity of antithrombin III by inducing a conformational change to factor $\mathrm{Xa}$, which ultimately leads to inhibition at Xa and Ila in a 1:1 ratio. Unfractionated heparin also has some inhibition on factors IXa, XIa, and XIIa. Low molecular weight heparins (LMWH), which also bind AT3, are smaller and have a higher proportional impact on Xa versus Ila, in a 3:1 or 2:1 ratio. Apart from these major classes, there are antiplatelet drugs like aspirin which is a cyclooxygenase (COX) inhibitor that irreversibly inhibits COX1 and, in higher doses, COX2. P2Y12 receptors are adenosine diphosphate (ADP) receptors expressed on the surface of thrombocytes; they can be blocked chemically by clopidogrel, prasugrel, and ticagrelor, which are in use, and cangrelor, which has recently been licensed. Other drugs such as glycoprotein IIb/IIIa inhibitors like abciximab, which is a humanized monoclonal mouse antibody, tirofiban, and eptifibatide are synthetic GpIIb/IIla inhibitors. Cilostazol and dipyridamole are phosphodiesterase inhibitors and proteaseactivated receptor- 1 antagonists; agents such as vorapaxar and atopaxar, inhibit platelet activation through alternative routes. The various drugs and mechanism of action are
Table 1 Commonly used anticoagulants and antiplatelets with their mechanism of action

\begin{tabular}{|c|c|c|}
\hline $\begin{array}{l}\text { Mechanism of } \\
\text { action }\end{array}$ & Drug name & Class of drug \\
\hline COX-1 inhibitor & Aspirin & \multirow[t]{12}{*}{ Antiplatelet drugs } \\
\hline \multirow[t]{5}{*}{ P2Y12 inhibitors } & Clopidogrel & \\
\hline & Prasugel & \\
\hline & Ticlopinine & \\
\hline & Ticagrelor & \\
\hline & Cangrelor & \\
\hline \multirow[t]{3}{*}{ Gp Ilb/IIla inhibitors } & Abciximab & \\
\hline & Tirofiban & \\
\hline & Eptifibatide & \\
\hline PAR-1 inhibitors & Vorapaxar & \\
\hline \multirow[t]{2}{*}{ PDE-3 inhibitors } & Dipyridamole & \\
\hline & Cilastazol & \\
\hline $\begin{array}{l}\text { Vitamin K } \\
\text { antagonist }\end{array}$ & Warfarin & \multirow[t]{5}{*}{ Anticoagulants } \\
\hline \multirow[t]{4}{*}{ Heparins } & $\begin{array}{l}\text { Unfractionated } \\
\text { Heparin }\end{array}$ & \\
\hline & Enoxaparin & \\
\hline & Dalteparin & \\
\hline & Tinzaparin & \\
\hline \multirow[t]{3}{*}{ Factor Xa inhibitor } & Fondaparinaux & \multirow{7}{*}{$\begin{array}{l}\text { Non-anti Vitamin K } \\
\text { anticoagulants }\end{array}$} \\
\hline & Rivaroxiban & \\
\hline & Apixaban & \\
\hline \multirow[t]{4}{*}{ Fibrinolytics } & Alteplase & \\
\hline & Reteplase & \\
\hline & Tenecteplase & \\
\hline & Urokinase & \\
\hline
\end{tabular}

detailed in - Table 1. Few caveats may be important to understand like heparin-induced thrombocytopenia risk is same with UFH and LMWH. Protamine sulfate can only help to partially reverse the effect of heparin: at most $60 \%$ of the anticoagulation effect of LMWH. In such a case, the best option is to use antifactor $\mathrm{X} .{ }^{2}$ Given the plethora of agents that any case of TBI can be on, it can be daunting to decide on the right course of management. Given below is a clinical scenariostage-wise management on the options and best course of management.

\section{Initial Management}

Management of head injuries depends on the severity of head injuries. Once a patients on anticoagulants presents with a head injury, we need to approach the management with care and the steps we need to follow are subdivided and detailed as follows:

1. Initial management and investigations for head injurybased on whether they are:

a. Mild head injury (GCS 14-15) or moderate and severe head injury GCS 13 and below. 
b. Investigations.

i. The initial computed tomography (CT) scan.

ii. Tests for coagulation.

c. Necessity for in-patient admission.

d. Serial follow-up (both clinical and radiological).

2. Management
a. Initial treatment and target internationalized normalized ratio (INR).
b. Reversal.
c. Use of adjuncts.
d. Restarting of anticoagulants.

\section{Initial Management of Head Injuries}

Internationally renowned guidelines such as Canadian CT head rule, New Orleans Criteria, NICE clinical guideline, and NEXUS II are based on the factors like mechanism of injury, patient age, comorbidities, and the neurological exam, but do not take anticoagulant use into consideration. While mild head injuries may still have a predictable course, the dilemma becomes deeper in case of moderate and severe injuries. However, for any patient who is on anticoagulants or has liver dysfunction or other coagulation disorders due to any medical or surgical reasons, a plain CT scan is justified in all cases. This is because the exact indications have not been clearly elucidated and not doing the same can risk missing a serious underlying pathology in cases with mild head injury. Only VKAs have been shown to increase mortality in TBI cases and other anticoagulants have had this effect only in very few studies. ${ }^{3-5}$ Hence, it may be appropriate to perform a CT scan in all cases to prevent missing an intracranial pathology.

Similarly, the course of a hematoma in such patients has not been demonstrated in literature. The only factors that can be thought to influence a hematoma are findings of the initial CT scan, the underlying risk factors, and the evolution of neurologic state and these may be considered while performing a repeat CT scan. A safer methodology would be to admit such a case for 24 hours despite the normal neurological examination and unremarkable CT scan. The only caveat would be aspirin monotherapy and a normal neurological and CT scan examination. The arbitrary limit of 24 hours is based on the risk of delayed bleeding which has been reported to affect 0.2 to $6 \%$ of TBI patients on VKAs or clopidogrel with normal findings upon repeat $\mathrm{CT} .{ }^{5}$ Thus, a safe methodology would be to perform a CT scan in those cases where a repeat examination shows deterioration and/or cannot be performed due to intubation, sedation, or dementia within 24 hours; and cases where such an examination does not show any findings the cases can be discharged after an observation period of 24 hours. The various scenarios are summarized in -Table 2 .

\section{Investigations}

After the initial management of the patient, need arises for them to undergo investigations related to the effect of anticoagulant drugs. Among the routine investigations that were performed are bleeding time (BT) and clotting time (CT). BT is defined as the time taken from the infliction of a wound to the arrest of bleeding ( $N=2-5 \mathrm{~min}$ ) and reflects platelet function and number. The clotting time (CT) has been defined as the time taken by a sample of blood to coagulate in vitro under standard conditions ( $N=8-15 \mathrm{~min}$ ). These tests, though useful, are abnormal only in severe disease and do not correlate with intraoperative bleeding. These factors along with a lack of standardization have resulted in them going out of common practice; but they are still used in many centers as a useful bedside indicator. Prothrombin time (PT) which is a test for the extrinsic pathway $(N=11-15 \mathrm{~s})$ is used to test the activity of factors VII and X. The internationalized normalized ratio (INR) is the ratio of PT that would be obtained if the international reference thromboplastin has been used to test the patient. Activated prothrombin time (aPTT) is the time required for plasma to clot when maximal surface contact activation and optimal phospholipid and calcium concentration are provided ( $N=35-45 \mathrm{~s}$ ). Thrombin time (TT) is the time required for the formation of a stable clot after the addition of thrombin to citrated plasma $(N=12-14 \mathrm{~s})$, that is, for the fibrinogen to form fibrin strands in vitro. Apart from these standard tests, there are mixing studies which are usually done in cases with an abnormally prolonged PT or aPTT. Here, adding an equal volume of the patient's citrated plasma to normal pooled plasma can perform a mixing study of the specimen. If the abnormal value normalizes after mixing, it indicates clotting factor deficiency in the plasma. Persistent prolongation of PT or aPTT after mixing suggests the presence of inhibitors in the plasma. ${ }^{3}$

When dealing with antiplatelets, the scenario might be different. These include platelet function tests like platelet function analyzer (PFA), impedance aggregometry (multiplate), and VerifyNow. These tests are capable of detecting and/or ruling out the presence of a platelet inhibitor. The intensity of platelet inhibition can be assessed; this allows for an estimation of the bleeding risk. This might be useful especially when the patient's medication is unknown. Platelet function tests are established methods for detecting disorders of the primary hemostatic capacity (e.g., von Willebrand syndrome) and monitoring antiplatelet drugs. Therapeutic ranges are established for the principal drugs (PFA, seconds [Siemens Package insert 2012-10]; Multiplate, the area under the curve [Roche Diagnostics Package insert 2016-12, V3.0 German]; and VerifyNow). However, these are certain drawbacks too. Notably, there is no evidence regarding residual inhibitory effects and the probability of accelerated bleeding when test results are outside the therapeutic range. These tests may (NOT ALWAYS) help differentiate nonresponders from noncompliant patients. Also, a poor correlation has been seen when these tests are compared to each other. ${ }^{4}$

Newer anticoagulants require special investigations. For example, TT or dilute TT (dTT) is used to rule out the presence of dabigatran anticoagulation. TT within the reference range excludes (remaining) dabigatran-associated anticoagulation while dTT (hemoclot) level $<30 \mathrm{ng} / \mathrm{mL}$ excludes (remaining) 
Table 2 Steps and scenarios of initial clinical management of a case of traumatic brain injury (TBI) on anticoagulants

\begin{tabular}{|c|c|c|}
\hline Question & Recommendation & Reasoning \\
\hline \multirow{4}{*}{$\begin{array}{l}\text { Should a CT scan be } \\
\text { performed in all patients } \\
\text { with suspected or known } \\
\text { TBI and potential or known } \\
\text { intake of oral anticoagu- } \\
\text { lants? All mild TBls too? }\end{array}$} & \multirow[t]{4}{*}{$\begin{array}{l}\text { All patients with suspected or known TBI and poten- } \\
\text { tial or known intake of oral anticoagulants require } \\
\text { a CT scan irrespective of anamnesis or neurological } \\
\text { examinations (e.g., Glasgow coma scale [GCS]) }\end{array}$} & $\begin{array}{l}\text { - Increased risk for intracranial pathologies in TBI } \\
\text { patients with coagulation disorders: may exhibit } \\
\text { normal neurological examination results and } \\
\text { normal anamnesis }\end{array}$ \\
\hline & & $\begin{array}{l}\text { - Of the available anticoagulants, only VKAs are } \\
\text { proven to increase TBI mortality, and in several } \\
\text { guidelines, these drugs are identified as an } \\
\text { indication to perform a CT. }\end{array}$ \\
\hline & & $\begin{array}{l}\text { - Antiplatelet drugs: some studies have reported } \\
\text { increased risks of intracranial pathologies and } \\
\text { mortality. }\end{array}$ \\
\hline & & $\begin{array}{l}\text { - Clear statements regarding the relative risks } \\
\text { in patients taking antiplatelet drugs cannot be } \\
\text { made. }\end{array}$ \\
\hline \multirow[t]{2}{*}{$\begin{array}{l}\text { Should a follow-up CT scan } \\
\text { be performed routinely? If } \\
\text { yes, when? }\end{array}$} & $\begin{array}{l}\text { - Patients with TBI and potential or known intake } \\
\text { of oral anticoagulants require a routine follow-up } \\
\text { CT scan only in case of ICH in the initial CT. }\end{array}$ & $\begin{array}{l}\text { - Course of ICH in the presence of coagulation } \\
\text { disorders cannot be predicted based on the } \\
\text { literature. }\end{array}$ \\
\hline & $\begin{array}{l}\text { When indicated, the follow-up CCT should be } \\
\text { performed between } 6 \text { and } 24 \text { h after the trauma. }\end{array}$ & $\begin{array}{l}\text { - The decision when to schedule the follow-up CT } \\
\text { may be influenced by the findings of the initial } \\
\text { CT, underlying risk factors and the evolution of } \\
\text { neurologic state. }\end{array}$ \\
\hline \multirow{7}{*}{$\begin{array}{l}\text { Should a patient with a } \\
\text { normal CT scan be admit- } \\
\text { ted for monitoring of the } \\
\text { neurological state? If yes, } \\
\text { for how long and what kind } \\
\text { of monitoring should be } \\
\text { used? }\end{array}$} & $\begin{array}{l}\text { - All patients with TBI and potential or known } \\
\text { intake of oral anticoagulants with a normal CT } \\
\text { should be admitted and observed for at least } \\
24 \mathrm{~h} \text { after trauma. }\end{array}$ & $\begin{array}{l}\text { - Numerous cases of delayed ICH in TBI } \\
\text { patients on anticoagulation with normal initial } \\
\text { neurological examination and CT scan findings. }\end{array}$ \\
\hline & $\begin{array}{l}\text { - A follow-up CT is indicated only in case of } \\
\text { neurological deterioration (changes in GCS and } \\
\text { pupil responses or FOUR score, as determined } \\
\text { by specialists in neurology, trauma surgery, } \\
\text { neurosurgery, or intensive care medicine). }\end{array}$ & \\
\hline & & $\begin{array}{l}\text { - Delayed bleeding: } 0.2-6 \% \text { of TBI patients on } \\
\text { VKAs or clopidogrel with normal findings upon } \\
\text { repeat CT. }\end{array}$ \\
\hline & $\begin{array}{l}\text { - Neurological examinations should be performed } \\
\text { every hour during the first } 4 \text { hour, every } 2 \text { hour } \\
\text { during the following } 8 \text { hour and every } 6 \text { hour } \\
\text { during the next } 12 \text { hour. }\end{array}$ & \\
\hline & & $\begin{array}{l}\text { - For TBI patients on anticoagulants whose initial } \\
\text { CT findings are normal, routine performance of a } \\
\text { repeat CT appears to be of little benefit. }\end{array}$ \\
\hline & $\begin{array}{l}\text { - Patients whose antithrombotic therapy } \\
\text { comprises ASA monotherapy only may be } \\
\text { discharged immediately under the following } \\
\text { conditions: normal initial CCT scan, GCS 15, } \\
\text { absence of other risk factors, and guaranteed } \\
\text { observation by nursing home staff or suitably } \\
\text { instructed close family/friends. }\end{array}$ & \\
\hline & & $\begin{array}{l}\text { - GCS and pupil responses or the FOUR score are } \\
\text { suitable for neurological evaluation. }\end{array}$ \\
\hline $\begin{array}{l}\text { How should we proceed } \\
\text { with patients with a normal } \\
\text { CT scan who cannot be } \\
\text { examined neurologically } \\
\text { (intubated, sedated, deliri- } \\
\text { ous, or noncooperative)? }\end{array}$ & $\begin{array}{l}\text { All patients with TBI and potential or known intake } \\
\text { of oral anticoagulants with a normal CCT scan who } \\
\text { cannot be examined neurologically (e.g., due to } \\
\text { intubation, sedation, or dementia) require a } \\
\text { follow-up CCT within 6-24 h after trauma. }\end{array}$ & $\begin{array}{l}\text { Since initial CT scan was negative a further CT scan } \\
\text { in cases where neurological examination is not } \\
\text { possible would be beneficial to rule out any new } \\
\text { injury/pathology. }\end{array}$ \\
\hline
\end{tabular}

Abbreviations: GCS, Glasgow coma scale; VKA, vitamin K antagonist; CT, computed tomography; ICH, intracerebral hematoma; CCT, cranial computed tomography. 
dabigatran-associated anticoagulation. TT measurement within the normal range excludes the presence of dabigatran anticoagulation since even low dabigatran concentrations (30-40 $\mathrm{ng} / \mathrm{mL}$ ) cause significant prolongation of the TT. It is not possible to use TT measurements for the quantitative determination of dabigatran or assessment of the risk of bleeding from dabigatran-mediated thrombin inhibition. Dabigatran level $<30 \mathrm{ng} / \mathrm{mL}$, likely to be observed $>4$ hours postdose, excludes a relevant risk of bleeding. It should be noted that the detection limit of the available dTT assays is $30 \mathrm{ng} / \mathrm{mL}$. When using apixaban, edoxaban, or rivaroxaban measuring antiactivated factor X (anti-Xa) activitycalibrated to LMWH or the specific "xaban" of interestis the method of choice. Calibrated to LMWH, an anti-Xa activity below the detection limit of the respective laboratory excludes (remaining) xaban-associated anticoagulation, whereas calibrated to the particular xaban, anti-Xa activity $<30 \mathrm{ng} / \mathrm{mL}$ excludes (remaining) xaban-associated anticoagulation. ${ }^{2}$ The various investigations are detailed in - Table 3.

Table 3 Investigations for coagulation function according to drug being consumed

\begin{tabular}{|c|c|c|}
\hline Drug & Test & Usefulness \\
\hline $\begin{array}{l}\text { Any } \\
\text { anticoagulant }\end{array}$ & $\mathrm{BT}, \mathrm{CT}$ & Bedside test \\
\hline \multirow{2}{*}{$\begin{array}{l}\text { Any antico- } \\
\text { agulant or } \\
\text { antiplatelet }\end{array}$} & \multirow{2}{*}{$\begin{array}{l}\text { PT, aPTT, INR, } \\
\text { mixing studies }\end{array}$} & - Useful baseline \\
\hline & & $\begin{array}{l}\text { - Mixing studies help } \\
\text { detect inhibitors in } \\
\text { plasma }\end{array}$ \\
\hline \multirow[t]{6}{*}{ Antiplatelets } & $\begin{array}{l}\text { - Platelet } \\
\text { function } \\
\text { analyzer (PFA) }\end{array}$ & $\begin{array}{l}\text { - Disorders of the } \\
\text { primary hemostatic } \\
\text { capacity (e.g., } \\
\text { von Willebrand } \\
\text { syndrome) }\end{array}$ \\
\hline & $\begin{array}{l}\text { - Impedance } \\
\text { aggregometry } \\
\text { (Multiplate) }\end{array}$ & \\
\hline & & $\begin{array}{l}\text { - Monitoring } \\
\text { antiplatelet drugs }\end{array}$ \\
\hline & & $\begin{array}{l}\text { - Resistance } \\
\text { to particular } \\
\text { antiplatelet drugs }\end{array}$ \\
\hline & - VerifyNow & \\
\hline & & $\begin{array}{l}\text { - Poor intertest } \\
\text { reliability }\end{array}$ \\
\hline Dabigatran & $\begin{array}{l}\text { Thrombin time } \\
\text { and dilute } \\
\text { thrombin time }\end{array}$ & $\begin{array}{l}\text { Even low dabigatran } \\
\text { concentrations } \\
\text { ( } 30-40 \mathrm{ng} / \mathrm{ml} \text { ) cause } \\
\text { significant prolongation } \\
\text { of the TT }\end{array}$ \\
\hline $\begin{array}{l}\text { Apixaban } \\
\text { edoxaban, } \\
\text { rivaroxaban }\end{array}$ & $\begin{array}{l}\text { Anti-activated } \\
\text { factor X (anti-Xa) }\end{array}$ & $\begin{array}{l}\text { Anti-Xa activity } \\
<30 \mathrm{ng} / \mathrm{mL} \text { excludes } \\
\text { xaban-associated } \\
\text { anticoagulation }\end{array}$ \\
\hline
\end{tabular}

Abbreviations: BT, bleeding time; CT, clotting time; PT, prothrombin time; aPTT, activated prothrombin time; CCT, cranial computed tomography; INR, internationalized normalized ratio; PFA, platelet function analyzer.

\section{Treatment}

Any goal of surgical treatment entails three main steps: maintaining target INR, the reversal of anticoagulation, and the use of adjuncts; the first and foremost of these is to decide on a target INR ( - Table 4). Textbooks have often mentioned a value of $<1.4$ INR for performing procedures but there is no substantiation of the same. ${ }^{6}$ A simpler methodology would be to reverse the INR in cases where a pathological finding is found on the CT scan of a TBI case. The reversal needs to be urgent as hemorrhagic lesions often progress during the early hours after trauma, and hemorrhagic progression of a contusion impairs clinical outcomes. ${ }^{7-10}$ In such cases, a target INR less than 1.5 and platelet count more than 1.35 lakhs/dL would be ideal, as any value other than these has been shown to be predictive of both radiographic and clinical worsening. Here a special mention of platelet concentrate transfusion needs to be made as to the findings as controversial. Downey et al ${ }^{11}$ investigated the effect of platelet transfusion in a retrospective study of $328 \mathrm{TBI}$ patients aged $>50$ years on Acetyl Salicylic Acid (ASA) or clopidogrel. Patients who received platelet transfusion had a similar mortality rate to those who were not treated with platelets (17.5\% vs. $16.7 \%$, respectively; $p=0.85$ ). Similarly, Ducruet et $\mathrm{al}^{12}$ studied 66 patients on antiplatelet therapy (ASA and/or clopidogrel) who suffered a primary ICH. Here, hematoma expansion was similar in transfused versus nontransfused patients. In another study, Briggs et $\mathrm{al}^{13}$ studied the effect of platelet transfusion in TBI patients, 12 on ASA and 5 not on ASA. ASA-induced component of platelet dysfunction but not the trauma-induced component was ameliorated by platelet transfusion.

Platelet transfusion and coadministration of DDAVP has not been associated with a decreased risk of hemorrhage progression or mortality. In a prospective study, ${ }^{14}$ DDAVP was administered to 10 patients with ICH who had been receiving ASA, and platelet function was improved; this effect was short-lived and not statistically significant. Naidech et $\mathrm{al}^{15}$ reported a study in patients with spontaneous intracerebral hematoma and reduced platelet activity. In patients $(n=7)$ treated with DDAVP within 12 hours of ICH symptom onset, a modest reduction in intracranial hematoma volume was observed (median $0.5 \mathrm{~mL}$ ).

No studies have investigated TXA in TBI patients on platelet inhibitors. A subgroup analysis of TBI patients $(n=270)$ recruited in the CRASH-2 study ${ }^{9}$ where the effect of TXA on ICH in patients with TBI was analyzed. CT scans performed before randomization and after 24 to 48 hours showed comparable mean total hemorrhage growth with versus without TXA (TXA group $5.9 \pm 26.8 \mathrm{~mL}$; placebo group, $8.1 \pm 29.2 \mathrm{~mL}$ ). A RCT (double-blind, placebo-controlled trial) by Yutthakasemsunt et al ${ }^{16}$ enrolled 238 patients with moderate to severe TBI (GCS 4-12) and no coagulopathy, and found that no significant difference in ICH progression was observed between the TXA group and placebo patients (risk ratio $[R R]=0.65$ ). The risk of death from all causes and the risk of an unfavorable outcome on the Glasgow outcome scale (GOS) were similar between groups $(\mathrm{RR}=0.69$ and 
$\mathrm{RR}=0.76$, respectively). Chakroun-Walha et al ${ }^{17}$ conducted a prospective, randomized trial of TXA in 180 TBI patients and found that mortality and 28-day GOS were similar in patients who received or did not receive TXA.

In the recently published CRASH-3 study ${ }^{18}$ which was conducted in 175 hospitals and 29 countries across the world, ${ }^{1}$ the authors have reported the results of a randomized, placebo-controlled trial of 12,737 adults with TBI (mean age 41.7 years [SD 19.0]; $80 \%$ men, $20 \%$ women) in which cases treated within 3 hours of injury had a reduced risk of head injury-related death, which was $18.5 \%$ in the tranexamic acid group versus $19.8 \%$ in the placebo group (855 vs. 892 events; RR 0.94 [95\% CI 0.86-1.02]). TA given very early ( $<3$ h) in cases of acute severe bleeding (traumatic and postpartum

Table 4 Steps and scenarios to be followed in the treatment of case of TBI on anticoagulants

\begin{tabular}{|c|c|c|}
\hline Scenario & Recommendation & Reason \\
\hline \multirow{3}{*}{$\begin{array}{l}\text { What is the target INR in } \\
\text { patients receiving VKAs when } \\
\text { the initial CT scan gives a } \\
\text { positive result? }\end{array}$} & \multirow[t]{3}{*}{ INR $<1.5$} & $\begin{array}{l}\text { - Patients with TBI and an INR }>2 \text {, the odds ratio for } \\
\text { ICH has been reported as } 2.59 \text { compared with TBI } \\
\text { patients not receiving warfarin. }{ }^{5}\end{array}$ \\
\hline & & $\begin{array}{l}\text { - Mason et al measured the INR upon emergency } \\
\text { room admission in } 2,934 \text { TBI patients. The median } \\
\text { INR of patients with an adverse outcome was only } \\
\text { slightly higher than in those with a good outcome } \\
\text { (2.5 vs. 2.4). }{ }^{6}\end{array}$ \\
\hline & & - INR $>1.2$ is associated with worse outcomes in ICH \\
\hline \multirow[t]{4}{*}{$\begin{array}{l}\text { When should reversal of } \\
\text { anticoagulants be done? }\end{array}$} & $\begin{array}{l}\text { - TBI without bleeding does not require } \\
\text { pharmacotherapy for anticoagulation } \\
\text { reversal. }\end{array}$ & $\begin{array}{l}\text { - Hemorrhagic lesions often progress during } \\
\text { the early hours after trauma, and hemorrhagic } \\
\text { progression of a contusion impairs clinical } \\
\text { outcomes. }\end{array}$ \\
\hline & $\begin{array}{l}\text { - Pathological findings in the initial CT scan: } \\
\text { temporary cessation of anticoagulant } \\
\text { medication and reversal of anticoagulation } \\
\text { should be considered. }\end{array}$ & $\begin{array}{l}\text { - Any case with a risk of contusion expansion or need } \\
\text { for surgery: immediate reversal. }\end{array}$ \\
\hline & & $\begin{array}{l}\text { - Patients on clopidogrel are more likely to have } \\
\text { progression of an initial ICH and a higher rate of } \\
\text { neurosurgical intervention, in comparison with } \\
\text { those receiving ASA. }\end{array}$ \\
\hline & & $\begin{array}{l}\text { - The impact of platelet inhibitors on mortality } \\
\text { remains unclear. }\end{array}$ \\
\hline \multirow[t]{2}{*}{$\begin{array}{l}\text { Should platelet concentrate be } \\
\text { administered to reverse the } \\
\text { effect of platelet inhibitors? }\end{array}$} & $\begin{array}{l}\text { - Routine use of platelet transfusion cannot } \\
\text { be recommended. }\end{array}$ & $\begin{array}{l}\text { Platelet transfusion could conceivably reduce } \\
\text { mortality following spontaneous intracerebral } \\
\text { hemorrhage in patients receiving platelet } \\
\text { inhibitors. }\end{array}$ \\
\hline & $\begin{array}{l}\text { - Platelet count }<135 \mathrm{G} / \mathrm{L} \text { in patients on } \\
\text { antiplatelet therapy is predictive of both } \\
\text { radiographic and clinical worsening. }\end{array}$ & $\begin{array}{l}\text { However, no studies have demonstrated clear } \\
\text { benefits in response to platelet transfusion in } \\
\text { hemorrhagic TBI patients on platelet inhibitors. }\end{array}$ \\
\hline \multirow[t]{4}{*}{$\begin{array}{l}\text { Should vitamin } \mathrm{K} \text { be adminis- } \\
\text { tered to reverse the effect of } \\
\text { VKAs? }\end{array}$} & $\begin{array}{l}\text { - Reversal of VKA anticoagulation is } \\
\text { always recommended in patients with } \\
\text { hemorrhagic TBI. }\end{array}$ & $\begin{array}{l}\text { - Reduction of INR to values less than } 1.4 \text { may take } \\
\text { up to } 24 \mathrm{~h} \text {. }\end{array}$ \\
\hline & $\begin{array}{l}\text { - However, it is recommended as an adjunct } \\
\text { treatment in these patients. }\end{array}$ & $\begin{array}{l}\text { - Non-life-threatening bleeding: IV vitamin } \mathrm{K} \\
\text { as monotherapy may be sufficient to achieve } \\
\text { adequate hemostasis within } 5 \mathrm{~h} \text {. }\end{array}$ \\
\hline & $\begin{array}{l}\text { - Dosage of } 5-10 \mathrm{mg} \text { administered } \\
\text { intravenously for at least } 3 \text { days. }\end{array}$ & $\begin{array}{l}\text { - TBI patients with ICH who are receiving VKA } \\
\text { therapy, vitamin } \mathrm{K} \text { is essential for sustaining } \\
\text { immediate reversal that is achieved using PCC. }\end{array}$ \\
\hline & & $\begin{array}{l}\text { - To ensure a rapid response, we recommend } \\
\text { parenteral rather than oral administration, and we } \\
\text { suggest a dose of 5-10 mg. }\end{array}$ \\
\hline \multirow{3}{*}{$\begin{array}{l}\text { Should PCC (prothrombin } \\
\text { complex concentrate) and/or } \\
\text { plasma be used for reversal of } \\
\text { VKAs? }\end{array}$} & $\begin{array}{l}\text { - Four-factor PCC is strongly recommended } \\
\text { in preference to plasma for treating } \\
\text { hemorrhagic TBI patients on VKAs. }\end{array}$ & $\begin{array}{l}\text { - PCCs normalize INR faster than plasma, and there } \\
\text { is evidence that quicker INR reversal reduces } \\
\text { hematoma expansion. }\end{array}$ \\
\hline & $\begin{array}{l}\text { - Initial dose of at least } 25 \mathrm{IU} / \mathrm{kg} \text { body } \\
\text { weight. }\end{array}$ & $\begin{array}{l}\text { Caution with plasma transfusion: requires the } \\
\text { administration of large volumes and is associated } \\
\text { with risks of circulatory overload, acute lung injury, } \\
\text { and immunosuppression. }\end{array}$ \\
\hline & $\begin{array}{l}\text { - Further doses should be administered if } \\
\text { needed to achieve INR }<1.5 \text {. }\end{array}$ & \\
\hline
\end{tabular}


Table 4 (Continued)

\begin{tabular}{|c|c|c|}
\hline \multirow{5}{*}{$\begin{array}{l}\text { Should recombinant acti- } \\
\text { vated factor VII (rFVIla) be } \\
\text { used for the reversal of VKA } \\
\text { anticoagulation? }\end{array}$} & \multirow[t]{5}{*}{$\begin{array}{l}\text { The available evidence shows no benefit from } \\
\text { using rFVIla versus PCC for the reversal of VKA } \\
\text { in hemorrhagic TBI. }\end{array}$} & $\begin{array}{l}\text { - rFVIla: in theory an alternative option for rapid } \\
\text { reversal of VKA anticoagulation in patients with } \\
\text { ICH. }\end{array}$ \\
\hline & & Two small retrospective studies: \\
\hline & & $\begin{array}{l}\text { First study: time to INR reversal was similar with } \\
\text { both treatments (PCC, } 784 \text { min; rFVIla, } 980 \text { min), } \\
\text { but INR rebound occurred more frequently in the } \\
\text { rFVIla group.? }\end{array}$ \\
\hline & & $\begin{array}{l}\text { - Second study: INR reversal }(\leq 1.3) \text { within } 1 \mathrm{~h} \text { was } \\
\text { achieved in } 83 \% \text { of patients treated with rFVIla } \\
\text { compared with } 20 \% \text { of those who received } \\
\text { three-factor PCC. }\end{array}$ \\
\hline & & $\begin{array}{l}\text { - Hematoma expansion occurred in a higher } \\
\text { percentage of patients in the rVlla group than in } \\
\text { the PCC group ( } 20 \% \text { vs. } 11 \%) .^{7}\end{array}$ \\
\hline \multirow[t]{4}{*}{$\begin{array}{l}\text { Should desmopressin (DDAVP) } \\
\text { be administered to reverse the } \\
\text { effect of platelet inhibitors? }\end{array}$} & $\begin{array}{l}\text { - There is no consistent evidence that } \\
\text { DDAVP administration in hemorrhagic } \\
\text { TBI patients on platelet inhibitors reduces } \\
\text { progression of intracranial hematoma or } \\
\text { improves neurologic outcome. }\end{array}$ & $\begin{array}{l}\text { DDAVP prompts the release of von Willebrand } \\
\text { factor and factor VIII from endothelial cells, } \\
\text { accelerating platelet adhesion and improving } \\
\text { primary hemostasis. }\end{array}$ \\
\hline & & $\begin{array}{l}\text { - DDAVP stimulates the expression of glycoprotein } \\
\text { receptor on the surface of platelets. }\end{array}$ \\
\hline & $\begin{array}{l}\text { - No clear recommendation for or against } \\
\text { the use of DDAVP. }\end{array}$ & \\
\hline & & $\begin{array}{l}\text { - Effectiveness in reducing the progression of } \\
\text { traumatic ICH is unknown. }\end{array}$ \\
\hline \multirow[t]{3}{*}{$\begin{array}{l}\text { Should tranexamic acid (TXA) } \\
\text { be administered to reverse the } \\
\text { effect of platelet inhibitors? }\end{array}$} & $\begin{array}{l}\text { - No evidence from randomized controlled } \\
\text { trials that TXA improves outcome in } \\
\text { hemorrhagic TBI. }\end{array}$ & $\begin{array}{l}\text { - Fibrinolysis: major contributor to poor outcomes } \\
\text { following trauma. }\end{array}$ \\
\hline & $\begin{array}{l}\text { - No clear recommendation for or against } \\
\text { the use of TXA in these patients. }\end{array}$ & $\begin{array}{l}\text { - Profibrinolytic activation: important component of } \\
\text { hemorrhage progression in TBI. }\end{array}$ \\
\hline & & $\begin{array}{l}\text { - Post CRASH-2 study9,10: TXA administration has } \\
\text { been implemented as standard therapy in many } \\
\text { trauma centers worldwide. }\end{array}$ \\
\hline \multirow[t]{6}{*}{$\begin{array}{l}\text { Should tranexamic acid (TXA) } \\
\text { be administered to all head } \\
\text { injury cases? }\end{array}$} & $\begin{array}{l}\text { - } \text { CRASH } 3^{18} \text { reported reduced risk of head } \\
\text { injury-related death which was } 18.5 \% \text { in } \\
\text { the tranexamic acid group versus } 19.8 \% \text { in } \\
\text { the placebo group ( } 855 \text { vs. } 892 \text { events; risk } \\
\text { ratio [RR] } 0.94 \text { [ } 95 \% \text { Cl } 0.86-1.02] \text { ) }\end{array}$ & - Multiple fallacies with the trial: \\
\hline & & $\begin{array}{l}\text { - Midtrial alteration of tranexamic acid time window } \\
\text { from } 8 \text { hto } 3 \mathrm{~h}\end{array}$ \\
\hline & & $\begin{array}{l}\text { - Only 9,202 patients received TA within } 3 \text { h which } \\
\text { did not meet the objective of } 10,000 \text { subjects. } \\
\text { - After excluding patients of GCS } 3 \text { and bilaterally } \\
\text { non-reactive pupils (NON-SALVEGABLE CASES) the } \\
\text { death rate was } 12.5 \% \text { in tranexamic acid group vs. } \\
14 \% \text { in the placebo group, so there is no statistical } \\
\text { difference in outcome in head injury-related } \\
\text { deaths. }\end{array}$ \\
\hline & & - No role of surgical intervention mentioned. \\
\hline & & $\begin{array}{l}\text { - All causes of death were head injury which is } \\
\text { unlikely in this heterogeneous population. }\end{array}$ \\
\hline & & $\begin{array}{l}\text { - Time window itself is a confounding factor as mild } \\
\text { injury may deteriorate later. }\end{array}$ \\
\hline
\end{tabular}

Abbreviations: TBI, traumatic brain injury; INR, internationalized normalized ratio VKA, vitamin $\mathrm{K}$ antagonist; CT, computed tomography; ICH, intracerebral hematoma; ASA, acetyl salicylic acid; IV, intravenous fluid; PCC, prothrombin complex concentrate; GCS, Glasgow coma scale; rFVIlla, recombinant factor VIla. 
hemorrhage) significantly increased overall survival from bleeding and survival benefit decreased by $10 \%$ for every 15 minutes of treatment delay until 3 hours, after which there is no benefit. Even after excluding patients of GCS 3 and bilaterally nonreactive pupils the death rate was $12.5 \%$ in tranexamic acid group versus $14 \%$ in the placebo group, so there is no statistical difference in outcome in head injury-related deaths (RR 0.94, CI 0.86-1.02). In this study, it was found that there was no significant reduction in death rates in severe TBI patients and a significant reduction in death rates in mild and moderate head injury patients with intracranial bleed. Effect of tranexamic acid on head injury-related death stratified by time to treatment is suggestive of the fact that earlier the treatment is given, better is the prognosis but severity of head injury is confounding factor and, thus, the trial failed to show an effect on two major parameters, that is, death and disability in head injury patients, but there was no increase in vascular occlusive events and morbidities. Hence, giving tranexamic acid to isolated TBI patients may not have a major change in their prognosis.

\section{When to Restart Anticoagulation?}

As with all chronic illness, the need for anticoagulation is life long and TBI forms an event in the due course of the drug. Here comes the all-important question of optimal timing and preferred agent for pharmacological prophylaxis in patients after hemorrhagic TBI. The updated Brain Trauma Foundation guidelines ${ }^{19}$ state that anti-thromboembolism medication can be reinitiated 24 hours after injury in patients who have a clinically and radiographically stable TBI. It also recommends LMWH as the agent of choice, at a dose suitable for patients with a high risk of thrombosis (e.g., subcutaneous enoxaparin 4,000 IU once daily). The reasons for such a recommendation are manifold. The reported incidence of venous thromboembolic events in isolated TBI varies from 3 to $25 \%$ when thromboembolism prophylaxis is delayed or not administered. Brain Trauma Foundation guideline recommends LMWH or unfractionated heparin (UFH) in combination with mechanical prophylaxis but the time frame for this treatment is not specified. In a systematic review of 14 studies it was shown that pharmacologic thromboembolism prophylaxis, administered 24 to 72 hours after injury, is well tolerated in patients with stable TBI, and 4 studies suggested that administering thromboembolism prophylaxis within 24 hour of injury does not lead to progressive traumatic ICH. ${ }^{19}$

While prophylaxis is understood, should therapeutic anticoagulation be resumed after hemorrhagic TBI? If yes, what should be the optimal timing? Here the evidence fails us. There is insufficient evidence to support or discourage the resumption of therapeutic antithrombotic treatment following TBI. Expertise from a multidisciplinary team with experience of clinical practice should be sought to guide decision-making on a case-by-case basis. A survey of practice patterns ${ }^{20}$ in patients with central nervous system hemorrhage and a history of atrial fibrillation and ischemic stroke showed that the most common times for restarting anticoagulation after the index hemorrhage was 1 month (43.5\%) followed by 1 week (33.7\%), respectively. Only $13.3 \%$ of respondents indicated they would prefer an earlier restart time (3 days) and $8 \%$ indicated they would not restart anticoagulation. Interestingly, $47.7 \%$ of respondents indicated that they face dilemmas at least once per week concerning anticoagulation restart time and intensity, and 59.4\% stated that they relied predominantly on intuition or experience. Thus, the answer lies in performing more clinical trials in this rarely discussed scenario. ${ }^{21}$

\section{Best Practice Guidelines}

Based on our review we can propose the guidelines given in - Table 5 in cases of TBI on anticoagulants.

\section{Conclusion}

The guidelines given borrow heavily from previously conducted trials and consensus guidelines ${ }^{20}$ and the reason remains poor availability of well-conducted trials in this

Table 5 Best practice guidelines in a case of $\mathrm{TBI}$ on anticoagulants

\begin{tabular}{|c|c|c|}
\hline \multirow[t]{4}{*}{ Diagnosis } & \multirow[t]{2}{*}{ CT scan } & $\begin{array}{l}\text { - Immediately after } \\
\text { admission }\end{array}$ \\
\hline & & - Repeat within 6-24 h \\
\hline & \multirow[t]{2}{*}{$\begin{array}{l}\text { Neurological } \\
\text { examination }\end{array}$} & $\begin{array}{l}\text { - GCS examination every } \\
4 \mathrm{~h}\end{array}$ \\
\hline & & $\begin{array}{l}\text { - Discharge if stable after } \\
24 \mathrm{~h}\end{array}$ \\
\hline \multirow[t]{4}{*}{ Tests and targets } & $\begin{array}{l}\text { Vitamin } \mathrm{K} \\
\text { antagonists }\end{array}$ & - Target INR $<1.5$ \\
\hline & \multirow{2}{*}{$\begin{array}{l}\text { Non-Vitamin } \\
\text { K anticoagu- } \\
\text { lants }\end{array}$} & - Dabigatran < $30 \mathrm{ng} / \mathrm{mL}$ \\
\hline & & $\begin{array}{l}\text { - Xabans: anti Xa target } \\
\text { value < } 30 \mathrm{ng} / \mathrm{mL}\end{array}$ \\
\hline & $\begin{array}{l}\text { Platelet } \\
\text { inhibitors }\end{array}$ & $\begin{array}{l}\text { Platelet function tests pref- } \\
\text { erably multiplate assays: no } \\
\text { target values }\end{array}$ \\
\hline \multirow[t]{4}{*}{ Reversal } & $\begin{array}{l}\text { Vitamin } \mathrm{K} \\
\text { antagonists }\end{array}$ & $\begin{array}{l}\text { Plasma concentrates to tar- } \\
\text { get INR }<1.5 \text { with Vitamin } \mathrm{K} \\
5-10 \mathrm{mg} \text { IV dose }\end{array}$ \\
\hline & \multirow{2}{*}{$\begin{array}{l}\text { Non-vitamin } \\
\text { K anticoagu- } \\
\text { lants }\end{array}$} & $\begin{array}{l}\text { - Dabigatran: } \\
\text { Idarucizumab } 2 \times 2.5 \mathrm{~g}\end{array}$ \\
\hline & & $\begin{array}{l}\text { - Xaban: Plasma } \\
\text { concentrates }\end{array}$ \\
\hline & $\begin{array}{l}\text { Platelet } \\
\text { inhibitors }\end{array}$ & No candidate for reversal \\
\hline \multirow[t]{2}{*}{$\begin{array}{l}\text { Resumption of } \\
\text { anticoagulation }\end{array}$} & Prophylaxis & $\begin{array}{l}\text { LMWH after } 24 \text { rs: } 4,000 \mathrm{IU} \\
\text { s.c once daily }\end{array}$ \\
\hline & Thrombolysis & $\begin{array}{l}\text { Case-by-case as per multi- } \\
\text { disciplinary team }\end{array}$ \\
\hline
\end{tabular}

Abbreviations: CT, computed tomography; GCS, Glasgow coma scale; INR, internationalized normalized ratio; LMWH, low molecular weight heparins. 
field. We have attempted to provide a pragmatic and practical approach to such cases with the hope that it will ensure minimum risks with the best possible patient outcomes. The entire journey from patient presentation to follow-up has been covered in this article and we hope this would be useful to all practicing in the field of neurotrauma.

\section{Conflict of Interest}

None declared.

\section{References}

1 Channabasavanna SM, Gururaj G, Das BS, Kaliaperumal VG, Epidemiology of Head Injuries in Bangalore. National Institute of Mental Health and Neuro Sciences. Bengaluru, Karnataka: Karnataka State Council for Science and Technology; 1993

2 Harter K, Levine M, Henderson SO. Anticoagulation drug therapy: a review. West J Emerg Med 2015;16(1):11-17

3 Madhugiri VS, Singh V, Kishore K, Reddy A, Bysani P. Perioperative management of patients on anti-platelet agents and anticoagulants and prophylaxis for venous thromboembolism in the neurosurgical setting-summary of evidence and practice guidelines. Current Pract Neurosci 2019;3:1-13

4 Deora H, Perez RM, Agrawal A, Salazar LRM. Commentary to: External Ventricular Drainage before endovascular treatment in patients with aneurysmal subarachnoid hemorrhage in acute period: its relation to hemorrhagic complications. Neurointervention 2019;14:1-3

5 Pieracci FM, Eachempati SR, Shou J, Hydo LJ, Barie PS. Degree of anticoagulation, but not warfarin use itself, predicts adverse outcomes after traumatic brain injury in elderly trauma patients. J Trauma 2007;63(3):525-530

6 Mason S, Kuczawski M, Teare MD, et al. AHEAD Study: an observational study of the management of anticoagulated patients who suffer head injury. BMJ Open 2017;7(1): e014324

7 Woo CH, Patel N, Conell C, et al. Rapid Warfarin reversal in the setting of intracranial hemorrhage: a comparison of plasma, recombinant activated factor VII, and prothrombin complex concentrate. World Neurosurg 2014;81(1):110-115

8 Pinner NA, Hurdle AC, Oliphant C, Reaves A, Lobo B, Sills A. Treatment of warfarin-related intracranial hemorrhage: a comparison of prothrombin complex concentrate and recombinant activated factor VII. World Neurosurg 2010;74(6):631-635

9 Shakur H, Roberts I, Bautista R, et al; CRASH-2 trial collaborators. Effects of tranexamic acid on death, vascular occlusive events, and blood transfusion in trauma patients with significant haemorrhage (CRASH-2): a randomised, placebo-controlled trial. Lancet 2010;376(9734) :23-32

10 CRASH-2 Collaborators, Intracranial Bleeding Study. Effect of tranexamic acid in traumatic brain injury: a nested randomised, placebo controlled trial (CRASH-2 Intracranial Bleeding Study) BMJ 2011;343:d3795

11 Downey DM, Monson B, Butler KL, et al. Does platelet administration affect mortality in elderly head-injured patients taking antiplatelet medications? Am Surg 2009;75(11):1100-1103

12 Ducruet AF, Hickman ZL, Zacharia BE, et al. Impact of platelet transfusion on hematoma expansion in patients receiving antiplatelet agents before intracerebral hemorrhage. Neurol Res 2010;32(7):706-710

13 Briggs A, Gates JD, Kaufman RM, Calahan C, Gormley WB, Havens JM. Platelet dysfunction and platelet transfusion in traumatic brain injury. J Surg Res 2015;193(2):802-806

14 Kapapa T, Röhrer S, Struve S, et al. Desmopressin acetate in intracranial haemorrhage. Neurol Res Int 2014;2014:298767

15 Naidech AM, Maas MB, Levasseur-Franklin KE, et al. Desmopressin improves platelet activity in acute intracerebral hemorrhage. Stroke 2014;45(8):2451-2453

16 Yutthakasemsunt S, Kittiwatanagul W, Piyavechvirat $\mathrm{P}$, Thinkamrop B, Phuenpathom N, Lumbiganon P. Tranexamic acid for patients with traumatic brain injury: a randomized, double-blinded, placebo-controlled trial. BMC Emerg Med 2013;13:20

17 Chakroun-Walha O, Samet A, Jerbi M, et al. Benefits of the tranexamic acid in head trauma with no extracranial bleeding: a prospective follow-up of 180 patients. Eur J Trauma Emerg Surg 2019;45(4):719-726

18 The CRASH-3 Collaborators. Effects of tranexamic acid (TA) on death, disability, vascular occlusive events and other morbidities in patients with acute traumatic brain injury: a randomised placebo-controlled trial. Lancet 394(10210): 1713-1723

19 Carney N, Totten AM, O'Reilly C, et al. Guidelines for the management of severe traumatic brain injury, fourth edition. Neurosurg; 2017 ;80:6-15

20 Hawryluk GW, Furlan JC, Austin JW, Fehlings MG. Survey of neurosurgical management of central nervous system hemorrhage in patients receiving anticoagulation therapy: current practice is highly variable and may be suboptimal. World Neurosurg 2011;76(3-4):299-303

21 Wiegele M, Schöchl H, Haushofer A, et al. Diagnostic and therapeutic approach in adult patients with traumatic brain injury receiving oral anticoagulant therapy: an Austrian interdisciplinary consensus statement. Crit Care 2019;23(1):62 